Dalia Šiukštiené

Generolo Jono Žemaičio Lietuvos karo akademija

\title{
Kinija: racionalieji lūkesčiai ir ekonominis nacionalizmas
}

\begin{abstract}
Kinijos transformacija iš pasaulio ekonomikos periferijos į branduolį vadinama ir globalizacijos siaubo, ir globalizacijos sèkmès pavyzdžiu; milžiniškais tempais besiplečiantis ekonominis ir politinis Kinijos potencialas tampa svarbiu iššūkiu tarptautinès sistemos status quo; šiame straipsnyje autorè, pasitelkdama pamatinius politinès ekonomijos teiginius, oficialią statistiką bei institucinius vertinimus, plètoja minti, kad Kinijos sugrị̌imą i dinamišką pasaulio ūkị po kelių dešimtmečiu autonomijos sąlygojo šalies politikos ir verslo elito gebejimas pasirinkti prioritetus ir taip išlaisvinti rinkos jẻgas, pasinaudoti finansinio kapitalo pertekliumi pasaulyje ir jo dèsningu judëjimu ị tas vietas, kur didžiausias ribinis pelningumas, ir kartu tikslingai manipuliuoti sinocentriškomis tautos nuostatomis; materializuodama viziją, kurią jai parodè industrinės valstybès, Kinija gali naudotis didžiuliu pranašumu - peršokti atskiras ekonominio vystimosi stadijas ir taip pralenkti bet kurị pramoninį lyderị, tačiau tampa akivaizdu, kad nacionaliné biurokratija, pernelyg pasiduodama gynybinio ekonominio nacionalizmo diktatui ir siekdama neproporcingai didelès ekonominès naudos sau, gali prarasti pagrindinį ekonominio augimo protrūkio stimuliatorių - užsienio investicijas.
\end{abstract}

\section{Ivadas}

„Kinijos dėka prekės Europos parduotuvėse yra pigesnės, verslo sąnaudos mažesnès, Europos bendrovès konkurencingesnès, rinkos Europos eksportuotojams didesnès, o palūkanos mažesnès", - $2006 \mathrm{~m}$. spalio $24 \mathrm{~d}$. džiaugèsi Peteris Mandelsonas, už prekybą atsakingas Europos Komisijos narys, pristatydamas naują ES ir Kinijos santykių strategijos dokumentą ${ }^{1}$. Jo pranešime buvo teigiama, kad Europa tiek politiniu, tiek ekonominiu požiūriu yra suinteresuota remti Kiniją, kad ji sẻkmingai taptų klestinčia, stabilia ir atvira šalimi, kur vadovaujamasi teisinės valstybės ir laisvosios rinkos principais. Prieš kelerius metus PPO generalinis direktorius Supachai Panitchpakdi kalbëjo, kad be Kinijos žmonijos istorijoje nebuvo kito ekonomikos pavyzdžio, kurį būtu galima įvardinti pasaulio ekonomikos varikliu, o pati Kinija - tai įkvèpimo šaltinis kitoms besivystančioms valstybėms ${ }^{2}$.

\footnotetext{
* Dalia Šiukštienè - ekonomistè, Lietuvos karo akademijos Politikos mokslų katedros lektorè. Adresas: Šilo g. 5 A, 10322 Vilnius, tel. 8-5-2103569, el. paštas - d.siukstiene@delfi.lt.

1 IP/06/1454, http://ec.europa.eu/trade/issues/bilateral/countries/china/index en.htm, 20080206.

2 Supachai Panitchpakdi, „Putting the Doha Development Agenda back on track: why it matters to China“, Speech at the International Forum ,,WTO and China “, Beijing, 10 November 2003.
} 
Po istorinio sąstingio aštuntojo dešimtmečio viduryje, kada Kinijos dalis buvo sumenkusi iki 8 proc. pasaulio BVP lygio, Kinijos ekonomika vẻl „grižta i sceną" - pagal 2007 m. duomenis, yra ketvirta pasaulyje po JAV, Japonijos ir Vokietijos. Tai, perfrazuojant Europos centrinio banko prezidento Jean-Claude Trichet minti, demonstruoja atgimstančią Kinijos galią, sietiną su faktu, jog 1820 m. Kinija kartu su Indija gamino apie pusę pasaulio produkcijos ${ }^{3}$.

Tačiau 2008 m. pasaulio spaudoje Kinija vis dažniau imama pravardžiuoti raju drakonu, kaltinama naujos kolonializmo bangos kẻlimu ir bandymu industrines valstybes palikti "ant ledo". "Naujuju“ kinu ,superalkis vartojimui“", pasak Tarptautinès energetikos agentūros, iki $2030 \mathrm{~m}$. privers patrigubinti naftos importą. O suklestèję fermeriai, kalnakasybos verslovès, naftos tiekejjai ir bankininkai jau mėgaujasi tokiais ekonomikos naujadarais, kaip „kylančių kainų biržos“, ,cikliška plètra“ ar ",superciklas“4.

Didejjanti Kinijos ūkio priklausomybẻ nuo neatsinaujinančių energetiniu ištekliu, o kartu ir pirmavimas pasaulyje pagal anglies, plieno, vario sunaudojimą, buvimas antraja valstybe po JAV pagal naftos ir elektros poreiki, verčia nerimauti tiek industrinių valstybiu, tiek pačios Kinijos politikos lyderius. Ryškus pramonės struktūros posūkis į sunkiąją pramonę reiškia dar didesni gamtinių ištekliu poreikį ir vis dramatiškesnes pasekmes pasaulio gyventojams. Vien tai, kad Kinijos metalurgijoje jau sunaudojama per 16 proc. visos šalies energijos (o jos pagrindas - akmens anglies deginimas), kai visiems šalies namų ūkiams tenka tik 10 proc. energijos ${ }^{5}$, žada dar daugiau rūgščių darinių atmosferoje bei nuolatini smogą Kinijos miestų gyventojams. Laiminami vyriausybės, Kinijos bankai moka labai menkas palūkanas savo indėlininkams ir „pigiai“ skolina pinigų valstybei priklausančioms įmonems. Pastarosios, valstybei mokẻdamos tik simbolinius žemès mokesčius ir dividendus, gali vis daugiau pelno nukreipti i gamybos plètrą ir nauju, bet vis tokiu pat energijos imlių ir aplinką teršiančiu gamybu vystymą. Tai reiškia, kad šiandieninės Kinijos gyventojai - banku indẻlininkai ir eiliniai mokesčių mokètojai - subsidijuoja savo šalies sunkiąją pramonę, kuri, deja, lètai, bet sistemingai juos pačius nuodija.

Tačiau būtų neteisinga problemų bei grésmių aplinkoje nepastebèti ir neįvertinti Kinijos politikos ir verslo elito gebejjimo pasirinkti prioritetus ir išlaisvinti rinkos jẻgas, išnaudoti visas galimybes, kurias, siekiantiems greito ekonominio ir pramoninio vystymosi valstybiniame ir privačiame sektoriuje, gali suteikti prekyba, užsienio investicijos bei technologijų importas. Kitaip tariant, politinis ekonominis Kinijos fenomenas įrodè, kad atsilikimas turi savu privalumų, o rinkos naujokai gali daug laimèti, taikydami agresyvią ir „neteisingą" taktiką.

Straipsnis neleidžia aprèpti visų šio fenomeno aspektų ir pokyčių tarptautinëje ekonominëje erdvëje, santykių su kitais didžiaisiais tarptautinès sistemos veikëjais - JAV, ES ar Rusija, kuriuos provokuoja auganti Kinijos

\footnotetext{
${ }^{3}$ Pagal Pasaulio banko informaciją (žr. www.worldbank.org, 200803 12).

${ }^{4}$ „The new colonialists“, The Economist, 15 March 2008, p. 13.

${ }^{5}$ Ten pat.
} 
galia. Todèl autorė apsiriboja prielaida, kad KLR makroekonominė politika yra pagrindinė arena, kurioje vyksta ir politinè konkurencija, ir siekia sau įdomiausio tikslo - patikrinti XX a. prognozes nūdienoje (2008 m.), ieškant koreliacijų su moderniais teoriniais požiūriais. Patyrusi, kad dauguma dabarties analitikų tarsi užstringa teorinių versijų lygmenyje ir paskęsta tautinëje savimeilëje, pernelyg pasinerdami į jègos balanso palaikymo ir geopolitiniu pokyčių atspindžius Kinijos ūkio strategijoje, teoretikų mintimis autorè naudojasi selektyviai. Laisvosios rinkos filosofiją atstovaujančio leidinio The Economist $2008 \mathrm{~m}$. informacijos ir tarptautinių verslo organizacijų apklausų bei statistikos duomenu interpretacija pateikiama trimis vienas kitą papildančiais skyriais, rišančiąja grandimi pasirinkus du aspektus. Pirmasis - tai racionaliujuc lūkesčiu aspektas, kurio svarba ekonomikai pripažistama nuo tada, kai Keyneso „Bendrojoje teorijoje", aiškinant investicijų svyravimus, buvo panaudota tikrojo gyvybingumo sąvoka ${ }^{6}$. Antrasis aspektas - tai dèl rinkos ypatybés kaupti turtą ir sukurti jègos santykius tarp nevienodos ekonominès galios šalių atsirandantis ekonominis nacionalizmas ${ }^{7}$. Toks analizès principas leidžia „išgryninti“ dvi naujas galimybes Kinijos ūkio plètrai bei dvi grèsmes, galinčias tapti stabdžiu realizuojant „pirmosios tarp lygiu“" valstybès viziją. Dvi naujos galimybès - tai infrastruktūros veiksnio, kaip galimo ekonomikos multiplikatoriaus, išnaudojimas ir pasaulio finansinio kapitalo pertekliaus ,,įdarbinimas“ šioje srityje bei sinocentriškų tautos nuostatų stimuliavimas, skatinant didinti pridètinę darbo vertę. Pirmoji grėsmè - tai nacionalinio lygio biurokratijos inercija ir siekis turèti viršenybę prieš regionu biurokratus, pasireiškiantis gynybinio ekonominio nacionalizmo sprendimais. Antroji - tai kylantis marksizmo ir Mao ideologinio paveldo lygis vidaus politikoje bei ideologijoje ir skatinantis antivakarietišką nacionalizmą bei dvigubų standartų egzistavimą harmoningos visuomenès inspiracijomis skatinamos, bet socialinės atskirties gniuždomos milijardinès tautos sąmonëje.

\footnotetext{
1995 m. Robertas Lucasas, už darbus apie lūkesčius gavęs Nobelio premiją, kartu su Thomu Sargentu šiuolaikinius žmonių lūkesčius pavadino racionaliais, nes jie formuojami nebe paprasta praeities ekstrapoliacija, o vadovaujantis racionaliomis prognozėmis. Teorija teigia, kad modernios makroekonomikos terpèje visada gyvuos tikejjimas, kad finansų rinka, žmonès ar įmonès darys viską, kad numatytų ateitį, kitaip tariant, savo veiklos pasekmes, geriausiu būdu pasinaudoję visa turima informacija (žr.: Blanchard, Oliver, Macroeconomics, New Jersey, Pearson Education, Inc., 2006, p. 387).

7 Ekonominis nacionalizmas reikšmingas tuo, kad šalies vartotojų ir visos visuomenės pajamos yra paskirstomos taip, kad laimėtų valstybès ginami gamintojai ir ji pati. Ekonominis nacionalizmas sukuria ekonomines rentas, atitenkančias interesų grupėms, kitaip tariant, visuomenès ekonominė gerovė yra aukojama atskirų grupių interesams - tai valstybès sandėris su gamintojais. Uoliausi ekonominio nacionalizmo šalininkai visais laikais visose valstybėse buvo nacionalinė biurokratija ir vidaus gamintojai, atstovaujantys ginamu gamybos sričiu interesus (žr.: Rostow, W.W. Politics and the Stages of Growth, New York: Cambridge University Press, 1971, p. 189).
} 


\section{Taikaus iškilimo filosofija ir kognityvinis disonan- sas dabartinèje Kinijos ideologijoje}

Apie technologinių ir kitų tipų inovacijų kilmę bei priežastis žinoma nedaug, akademiniuose straipsniuose dažnai aiškinama, kad egzistuoja stiprus inovaciju polinkis kauptis laiko ir vietos atžvilgiu. Tam tikrų valstybių ekonomikoje jos, esą, atsiduria tam tikru laiku. Tik nuo santykinio efektyvumo ir santykinio pranašumo priklauso, kur ir kada inovacijų centrams lemta iškilti ir smukti. Kaip kažkada savo tyrinejjimuose apie vėlyvają Rusijos industrializaciją yra pažymëjęs Leonas Trockis, egzistuoja „,kombinuoto ir netolygaus vystymosi dèsnis“. Pasak dèsnio, kopiant technologiniais laiptais, ryškiausiu rezultatų lemta pasiekti valstybėms, skatinančioms užsienio technologijų importą bei gebančioms suderinti šias technologijas su tradiciniais visuomenès modeliais ${ }^{8}$.

XX a. pabaigos pokyčiai pasaulio ūkio struktūroje, o ypač netikètas Kinijos ūkio augimas, iš esmès sugriovè politinès ekonomijos teiginius apie tai, kad mažiau išsivysčiusios valstybès nesugebės plèstis nereformuoto pasaulinio kapitalizmo sistemoje. Kinijos atvejis, rašančius politinės ekonomijos temomis, privertẻ atsiriboti nuo prieš kelis dešimtmečius išpopuliarëjusių teiginiu, kad nacionalinių valstybiu ir politinių sienu pasaulyje yra neišvengiami konfliktai, kai kylančios valstybės ar atskiros ekonomikos šakos bando įveikti egzistuojančius barjerus. Pastaruoju metu mokslo tyrinejjimuose ir publikacijose populiareja mintis, jog kinų tauta yra seniai suvokusi, kaip turi gyventi „,teisingai sutvarkyta hierarchinè visuomenė“, o siekis atkurti teisingumo principą provokuoja jos tikslą susigrąžinti anksčiau turètą galią regione bei pasaulyje ir taip stimuliuoja atitinkamus veiksmus ${ }^{9}$.

\subsection{Nauja strategija - būti „,pirmaja tarp lygiụ“}

Dera prisiminti, kad autonominio vystymosi kelią, paremtą socialistinėmis šalies reformomis, prieš 5 dešimtmečius buvo pasirinkusios net kelios valstybès. Jos deklaravo norą kaip galima mažiau įsitraukti i tai, ką vadino priešiško imperialistinio pasaulio kapitalistiniu ūkiu. Teoriniuose darbuose toki kelią siūlè ir valstybių pasirinkimą gyrè kai kurie priklausomybès teorijos šalininkai. Kelios valstybès - Kuba, Tanzanija ir Kinija - išties pasiekẻ tam tikrų gerovės bei ekonominio teisingumo strategijos tikslų.

Tačiau, kaip teigia Kinijos ekonomikos analitikai, socialinëje ir ūkinëje srityje lauktų rezultatų nebuvo per ilgai ${ }^{10}$, o Mao Zedung paskelbta „Didžiojo

\footnotetext{
8 Knei-Paz, Baruch, The Social and Political Thought of Leon Trocky, Oxford, Clarendon Press, 1978, p. 89.

9 Castro, R., „Exploring the Prospect of China's Peaceful Emergence in East Asia“, Asian Affairs: An American Review, Vol. 33 Issue 2, 2006, p. 86.

${ }^{10}$ Rydenfelt, Sven, A Pattern for Failure: Socialist Economies in Crisis, San Diego: Harcourt Brace Jovanovich, 1985 , p. 204-213.
} 
šuolio pirmyn" programa (1958-1961) žlugo, kai buvo atsiribota nuo Sovietų Sajungos. Kilusi kultūrinè revoliucija dar stipriau sudarkẻ mokslinę ir techninę šalies bazę, ūkį. Prireikẻ dešimtmečių, kol Deng Xiaoping, ị valdžią atëjęs po Mao mirties, prakalbo, kad jokia šalis negali vystytis „užsidariusi duris“, nes būtent izoliacija, esą, atvedẻ Kiniją į skurdą, atsilikimą ir nežinojimą ${ }^{11}$.

Akademikų darbuose, bandant nustatyti šiuolaikinès Kinijos vietą pasaulio sistemoje, jos geopolitinė tapatybė ir užsienio politika dažnai aiškinamos „teisingos vietos pasaulyje“ atgavimo filosofija ir tradicinėmis konfucionistinèmis vertybėmis - pasididžiavimu savo istorija ir civilizaciniais pasiekimais, universalios ir visavertès harmonijos siekimu. Net Lietuvos politologai, remdamiesi kinu geopolitinès tapatybès tyrinètoju teiginiais apie tai, kad etnocentriškas jų valstybès iškilimas yra savaime suprantamas dalykas, atkreipia dėmesi i frustracijas dèl to, kad Kinija vis dar nèra pirmoji pasaulio valstybé $\dot{e}^{12}$.

„Taikus iškilimas“ Kinijos užsienio politikos koncepcijoje, atsiradęs taip vadinamu ketvirtosios lyderių kartos laikotarpiu, atspindi modernią Kinijos imperialistinę ideologiją. Pasak įvairių šaltinių, tokia ideologija yra paremta ekonominio, karinio, socialinio ir kultūrinio bendradarbiavimo tarp kaimyninių valstybių siekiu, kuris būtų abiem pusėms naudingas. Todèl Kinijos, arba Vidurio valstybès, kaip ją vadina patys kinai (kinų k. Zhongguo), vaidmuo bendravime būtų ne vienareikšmiškai kontroliuoti, o būti „pirmaja tarp lygiü" valstybe. Nuolatinis visuomenès nepasitenkinimo turimais ekonomikos pasiekimais stimuliavimas ir kinų tautoje giliai glūdinčio „istorinės skriaudos“ jausmo skatinimas provokuoja savo jègą jau įrodžiusius prarastos regioninès galios atkūrimo lūkesčius ${ }^{13}$. Žinant, kad visas socialines ir ekonomines tendencijas galima vertinti, pasitelkiant konceptualius matematikos teiginius, Kinijos ekonomikos atžvilgiu prasmingu tampa didžiujų skaičių dėsnis, leidžiantis sudèlioti bet kokiu įvykių seką i a aiškią grandinę. Tokiu būdu dèsnį atsargiai interpretuodami ir pasinaudoję 1 proc. sąvokos pavyzdžiu, galime hipotetiškai įvertinti ,,istorinès skriaudos atitaisymo" lūkesčių potenciją ir įtaką ne tik tolimesnei Kinijos, bet ir pasaulio sistemos raidai ${ }^{14}$. Nors ekonomine istorija pateikia atveju, kai žmonès, įmonės ar finansų rinkos dalyviai, praradę realybės pojūti, tapdavo pernelyg dideli optimistai ar pesimistai, o jų lūkesčiams nebuvo lemta realizuotis, tačiau visi žinomi atvejai dažniausiai būdavo susiję su techniniu ir informaciniu ribotumu. Šiuolaikinès komunikaciju technologijos,

\footnotetext{
${ }^{11}$ Ten pat.

${ }^{12}$ Lopata R., Statkus N., „Imperijos, pasaulio tvarka ir mažosios valstybės“, Lietuvos metine strategine apžvalga 2005, p. 51.

${ }^{13}$ Pasak atskirų šaltinių, kinai savo šalies iškilimą vertina kaip teisingumo išsipildymą - savaime suprantamą dalyką susigrąžinant prarastą statusą. Didžiuodamasi savo istoriniais ir civilizaciniais pasiekimais, tauta natūraliai priima Kinijos galios grį̌imo procesą - tarsi jis būtų istoriškai determinuotas, ir tuo pačiu reiškia nusivylimą dabartine padėtimi [žr.: Lopata, (note 12)].

${ }^{14}$ Jei 100 žmonių bendruomenejje teisingumo reikalauja tik vienas, likusieji 99 tiesiog nereaguoja. Jei 1000 žmonių bendruomenèje mitinguos 10 asmenų, 990 juos užgoš savo abejingumu. Kinijos atveju, kai gyventojų - 1,3 mlrd., galime tikètis, kad apie šalies „,teisingą padėti““ kalbės šimtai tūkstančių kinų ir tokiomis mintimis paveiks kitus šimtus tūkstančių; kai jų skaičius pasieks kritinę masę, kiekis ims daugintis savaime, jèga darysis stipresnè, nei procentinio santykio sąvoka leido tikètis.
} 
pvz., internetas, jau suteikia neribotas galimybes stiprèti individų tarpusavio ryšiams ir taip didèti lūkesčių realizavimo galimybėms.

Kinijos politinės jẻgos demonstruoja tikrai išmoningą manipuliavimą sinocentristiškomis tautos nuostatomis ir tradicinėmis vertybėmis, formuojant ekonominès, politinès ir kultūrinès-civilizacinès įtakos zoną. Prieš penkerius metus kinai buvo skatinami didžiuotis, kad jau pradejjo vykdyti savo kosminę misiją, o pasiekimais po kelerių metu pasivys JAV ir Rusiją, 2007 m. - kad ju tautiečiai jau parengti skristi į mėnuli, 2008 m. - kad surengé prabangiausias sporto istorijoje neriboto biudžeto Olimpines žaidynes ir iૃrodẻ pasauliui, kad yra ne tik didžiausia, bet ir ",sportiškiausia“ tauta. Pagaliau nors vienoje srityje buvo aplenktos Jungtinès Amerikos Valstijos, kinu komandai gavus 100 olimpinių apdovanojimų ir absoliučiai daugiausia aukso medaliu, kurių laimètojams vyriausybė skyrè ir didžiausias pasaulyje premijas - po $1 \mathrm{mln}$. JAV dolerių.

Visais laikais turëjusi daug stiprios valstybės privalumų, daug ekonominių išteklių ir palyginti didelę vidaus rinką, Kinija nepajègè igyvendinti autonominio vystimosi strategijos. Akivaizdu, kad po kelių dešimtmečių autonomijos grįžti i dinamiškai besivystantį pasaulio ūkį Kinijai gali padèti tik kitų valstybiu ekonomikos pasiekimai - investicijos iš Vakaru, modernios technologijos bei "atvira“" prekyba. Tačiau akivaizdu ir tai, kad Kinijos ekonomikos atgaivinimo kampanija buvo ir tebėra grindžiama Mao laikais įsitvirtinusiu ir kognityviniu disonansu aiškinamu šūkių poveikiư ${ }^{15}$.

\subsection{Mao ivaizdis - irankis didinti valstybès galią}

Pasak Kinijos atvejo tyrinėtojų, valstybès istorijoje buvo vienintelè asmenybè, imperatorius Qin Shi Huang, pradejjęs statyti Didžiają kinų sieną, savo populiarumu ir ịtaka milijardinès tautos sprendimams prilygstantis $1976 \mathrm{~m}$. mirusio Mao įtakai. Nors buvusio vadovo ideologinio palikimo įtaka dabartiniam ekonomikos vystimuisi vertintina kaip simboliška, tačiau Mao portretas ant šiandieninės Kinijos banknotu, kelionės krepšių ir apsipirkimo krepšelių, sagių ir ženkliuku, laikrodžių ir kitokių plačiai pardavinẻjamų smulkmenų yra nepaprastai reikšmingas. Dirbantiems ir kuriantiems žmonėms Mao atvaizdu ir šūkiais nuolat primenama inovacijų svarba, nuolatinẻ konkurencija ir privalomas savikritiškumas. Nors, kaip dabar iprasta vertinti, to meto Kinijos ekonomikos pasiekimai buvo skurdūs, ekonominè politika - be „karkaso“, o vadovavimas - „be smegenu“", bet kokia iniciatyva ar deklaruojama inovacija atrodè virsianti nauja įcentrine jèga valstybės galiai didinti. Valdymo mokslas tokią įtaką vadintų restruktūrizavimo poveikiu - kuo plačiau išsklaidysi veiklą ir funkcijas, tuo lengviau pasislèpsi nuo atsakomybès.

Po Mao laikotarpio atsigavusi Kinijos ekonomika bei valstybės „lopymo

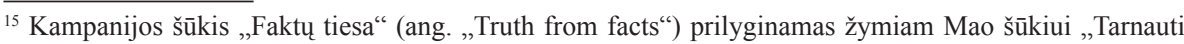
žmonėms“ (ang. „Serve the People“), nes abu visuomenèje kelia nuoširdų tam tikrų dalykų pripažinimą ir pasitikejjimą jais, nors iš tikrujų valstybejje daroma kas kita (žr.: „Staying at the top“, The Economist, 22 December 2007, p. 116).
} 
politikos" igyvendinimas, daug kitu geru pasiekimu yra siejami su Deng Xiaoping vardu. Šio šalies vadovo retorika padejo sukurti keturių modernizaciju programą ir atkreipti pasaulio dėmesị i šiuolaikišką, socialiai orientuotą, rinkos ekonomiką bei supervalstybės padèti atitinkančią gynybos sistemą, tačiau jo atvaizdo net ant menkos vertès monetos nèra. O Mao îvaizdžio galios pavyzdys - tai tūkstančiu žmoniu vienybẻ kritinëje situacijoje po $2008 \mathrm{~m}$. gegužès 12 d. žemès drebëjimo Kinijos pietvakarinëje dalyje, Sichuan provincijoje, kai vadinamieji „viduriniosios klasès" atstovai nuosavais ir taksi automobiliais organizavo „skubų traukinį" gabenti nukentejusius ${ }^{16}$. Kaip vèliau sarkastiškai komentavo pasaulio spauda, Kinijos ministrui pirmininkui Wen Jiabao teliko „paskubèti, kad nepavėluotu į sceną ir penkias dienas vaidintų apsiašarojusį gelbẻjimo operacijų vadovą̨"17.

Manytina, kad dabartinès Kinijos ekonomikos politikos formuotojai, siekdami valdyti milijardo žmoniu protus ir darbo rezultatus, stengsis kaip įmanoma ilgiau išlaikyti kognityviniu disonansu paaiškinamą Mao įvaizdžio įtaką. Tai reikštų sẻkmingą manipuliavimą moderniais ir savo galią Kinijoje jau įrodžiusiais įvaizdžio palaikymo būdais. Jais valdymo mokslo specialistai įvardintų skambių šūkiu populiarinimą, "aštrios" spaudos įvaizdžio palaikymą, ištikimų bendraminčių rato subūrimą bei žmonių aistros kurti planus ir vizijas išnaudojimą. Juk dar žymusis novelistas Edgaras Po yra pastebëjęs, kad žmogaus gyvenimas laimès yra kupinas daugiausia dèl to, kad žmogus amžinai laukia, jog netrukus taps laimingas.

\section{Keturių modernizacijų programos dvasia}

Pasaulinės ekonomikos augimo ir struktūriniu pokyčiu istorija - tai veiklaus liberalizmo, atvirumo ir laisvosios prekybos laikotarpių susipynimas su stagnacijos, protekcionizmo ir nacionalinių konfliktų laikotarpiais. Struktūriniai pokyčiai valstybėse provokuoja ekonominius konfliktus, todèl teorijoje imamasi naujų vidaus veiksnių analizės, pavyzdžiui, iškeliant interesu grupių faktorių. Dèl egzistuojančio tiesioginio ryšio tarp pramonès ir visos ekonomikos vystimosi, tarp ekonominio apsirūpinimo ir politinės autonomijos, tarp

\footnotetext{
${ }^{16}$ Buvo pranešta, kad apie 74 tūkst. žuvę ir dingę be žinios, 247 tūkst. sužeisti ir 5 mln. žmonių, kurie likę be pastogès. Tokia nelaimè kinų tautą ištiko tuo metu, kai šalies vyriausybė dorojosi su nacionalizmo protrūkiu dèl Tibeto klausimo, negatyviu Vakarų valstybių požiūriu i susidariusią situaciją bei artèjančių Pekino olimpinių žaidynių problemomis. Buvo aišku, kad ịprastos pajègos - armija ir specialieji civilių gelbėtoju padaliniai, komunistinio jaunimo lygos aktyvistai bei Kinijos raudonasis kryžius - bus bejègès susitvarkyti sudarkytoje Sichuan provincijos zonoje. „Come on China!“, - tokị visomis kalbomis suprantamą šūkị, pasak stebėtojų, pirmieji skandavo 100 tradiciniais darbo drabužiais vilkinčių žmonių, su žvakėmis, raudonomis vẻliavėlèmis bei Mao portretais rankose policijos automobilių šešèlyje marširavusių tamsiomis Chengdu, provincijos sostinès, gatvėmis. Palydimi sentimentaliais komentarais, šie vaizdai, retransliuoti per daugybę žiniasklaidos kanalų, per naktį pakeitė situaciją nukentèjusioje provincijoje (žr.: „China helps itself", The Economist, 24 May 2008, p. 68).

${ }^{17}$ Ten pat.
} 
karinès galios ir nacionalinès nepriklausomybės visos šiuolaikinès valstybès siekia turèti modernią pramonę. Kinijos atveji galima pagrįsti dar K. Marxo suformuluotu teiginiu, kad mažiau išsivysčiusios šalys siekia perimti pažangias technologijas iš valstybės hegemono arba kitų išsivysčiusių valstybių. Tai reiškia, kad prieš kelis dešimtmečius kelios pramoniniu požiūriu išsivysčiusios šalys menkai išsivysčiusiam kraštui, t. y. Kinijai, parodẻ jo paties viziją. Dabar Kinija jau naudojasi ypatingu pranašumu -ji gali peršokti atskiras ekonominio vystymosi stadijas, taip pralenkdama bet kuri pramoninį lyderį ${ }^{18}$. Norèdama sukurti efektyvią masto ekonomiją ir gauti reikiamų užsienio valiutos ištekliu bei pagrindinio kapitalo importui finansuoti, ji aktyviai skverbiasi i pasaulio rinką, o, veikdama sèkmingai ir turèdama mažesnio darbo užmokesčio struktūrą, gali ne tik konkuruoti, bet ir susilpninti ekonomiškai stiprių šalių pozicijas atskirose ekonomikos srityse ${ }^{19}$.

Sutinkant su prielaida, kad kiekvienos naujos pramoninès valstybės iškilimo pasekmėms didžiausią įtaką daro pokyčių sparta ir santykinio pranašumo difuzijos laikas ${ }^{20}$, verta prisiminti, kad Kinijos keturiu modernizaciju programa vykdoma jau nuo 1978 m. Jos tikslas - deklaruojamas siekis sukurti šiuolaikišką, socialiai orientuotą rinkos ekonomiką ir šaunios valstybès padėtį atitinkančią gynybos sistemą. Tuo metu pasaulyje daugėjo sunkumų dèl vis spartëjančiu pranašumo pokyčių ir išorinių sukrètimų. Staigiai keturgubai padidejjus energetinių išteklių kainoms, pasikeitė vartotojų poreikiai, o pirmaujančių pasaulio valstybiu kapitalo fondai ėmė atrodyti atgyvenomis. Ekonomikos analitikai ir progresyvūs politikos lyderiai èmé pastebèti, kad atsilikimas turi savų privalumu, jog pirmauti ne taip jau ir lengva, o tokioje situacijoje rinkos naujokai gali daug laimèti, taikydami agresyvią ir "neteisingą" taktiką ${ }^{21}$.

\subsection{Infrastruktūrų bumas - naujasis ekonomikos multiplikatorius}

2008 m. pasaulio statistikos duomenys rodo, kad vizijos, kurias menkai išsivysčiusioms valstybėms daug metų rodė industrializuoti kraštai, buvo suvoktos kaip iš tikruju pasiekiamas tikslas - kalbama apie didžiausią kada nors pasaulio ūkyje buvusį investicijų į infrastruktūrą bumą besivystančiose šalyse. Pasak analitiku, jose per artimiausius $10 \mathrm{~m}$. bus investuota apie 22 trilijonus JAV dol., vykdant automagistraliu, geležinkelio, elektros perdavimo linijų tiesimo

\footnotetext{
${ }^{18}$ Sen, Gautam, The Military Origins of Industrialization and International Trade Rivalry, New York: St. Martin's Press, 1984, p. 15.

${ }^{19}$ Pvz., Amerikos firmos Samsonite sprendimai: $30 \mathrm{~m}$. lagaminus gaminusi Belgijoje, $1997 \mathrm{~m}$. firmą perkèlè i Slovakijos miestą Samorin, kur tuo metu bedarbystė siekẻ 20 proc. Po 9 m., kai Slovakijos darbininkai ėmè reikalauti „europietiškų“ atlyginimų, Samsonite atleido 350 slovakų, uždarè i̇monę ir perkèlè gamybą i Kiniją. ES restruktūrizacijos stebèjimo agentūra (ERM) skelbia, kad vien tarp ES „naujokių“ panašių atvejų suskaičiuojama per 20 .

${ }^{20}$ Pasak G. Seno, iki Kinijos iškilimo santykinai trumpu laikotarpiu žymiausią dali pasaulyje gamino D. Britanija (laikotarpis po Napoleono karų iki XIX a. pab.), Vokietija (1890-1913), JAV (po 1890 m. ir dabar), Japonija (1981 m. pripažinta svarbiausia kapitalo eksportuotoja) [žr.: Sen (note 18)].

${ }^{21}$ Rostow, W.W. Politics and the Stages of Growth, New York: Cambridge University Press, 1971, p. 64.
} 
bei telekomunikacijų projektus. 43 proc. (apie 9,3 tril. JAV dol.) šių investicijų teks Kinijai ${ }^{22}$. Tu pačių šaltinių duomenimis, pastaruosius penkerius metus infrastruktūros projektai Kinijoje vidutiniškai sudarẻ apie 12 proc. BVP, taigi per paskutinius 5 metus realios naudos šioje srityje sukurta tiek, kiek per visą XX a., nors dauguma ekonomistų teoretikų pripažįsta, kad gera infrastruktūra visada buvo svarbiausia greito valstybių ekonominio augimo ${ }^{23}$ prielaida, tačiau yra nuomonių, kad valstybių išlaidavimas infrastruktūros projektams - tai ekonominio augimo pasekmè. Manoma, kad Kinijoje poreikis elektrai, būstui ir sanitariniam aptarnavimui, susisiekimo paslaugoms auga, praturtëjusiems „kaimiečiams“ vis aktyviau migruojant gyventi į miestus.

O didejjanti paklausa visada provokuoja investuoti į perspektyvias sritis. Modelį, nustatantį ateities investiciju i i infrastruktūrą paklausos ir bendrojo ekonomikos, gyventoju skaičiaus bei urbanizacijos lygio koreliaciją, aktyviai propaguoja, pavyzdžiui, Goldman Sachs bankas. Jo specialistai paskaičiavo, kad jei santykinẻ dalis kinu, gyvenančių miestuose, padidẻja 1 proc., tai, pavyzdžiui, suminis elektros galingumas vartotojams turi būti didesnis 1,8 proc. Kai pajamų 1 kinui dydis išaugs 1 proc., paklausa elektros energijai šalyje padidès 0,5 proc., oro liniju keleivių skaičius $-1,4$ proc. ir t.t. Tokia logika leidžia prognozuoti, kad per artimiausią dešimtmetį suminis elektros galingumas Kinijos vartotojams turès būti didesnis 140 proc., kad keliaujančių lèktuvais skaičius išaugs iki 3,5 karto, (tai reiškia ir nauju oro uostų statybos bumą), o fiksuoto ryšio telefonijos vartotojų skaičius gali padidèti net 13 kartų. Kitaip tariant, šiandieninės Kinijos infrastruktūros plètrą, kuri kartais vadinama ekonominio augimo prielaida, kartais - jo pasekme, teisinga būtų pavadinti moderniausiu ekonomikos multiplikatoriumi ${ }^{24}$.

Pirma, dèl investicijų į infrastruktūrą atsiras naujų darbo vietų, nes reikès tiesti automagistrales ir vietos kelius, geležinkelius ir telekomunikacijas. Antra, taip didinamos visuomenės pajamos bei skatinamas greitas vartojimas. Trečia, gerëjant susisiekimui, ūkininkai iš atokių provincijų vis daugiau žaliavų pristatys į miestus, o perdirbëjai eksportuos daugiau savo produkcijos. Ketvirta, auganti statybinių medžiagų ir įrengimu paklausa išlaikys aukštas jų kainas, o tai išlaikys ir aukštą kitų vartojimo prekių kainų lygị. Tai skatins plèsti gamybą pačioje Kinijoje arba importuoti papildomus gaminių kiekius, tai toliau mažins Kinijos einamosios sąskaitos perteklių. Jei Kinijai pavyks išlikti valstybe su žemiausiais transportavimo kaštais, tai šalis ir toliau mėgausis augančiais užsienio prekybos ir bendraisiais ekonomikos rodikliais. Pasaulio banko skaičiavimu, investicijoms į Kinijos infrastruktūrą padidèjus 1 proc., tiek pat, tikètina, didès ir šalies BVP.

\footnotetext{
${ }^{22}$ „Building BRICs of growth“, The Economist, 7 June, 2008, p. 80.

${ }^{23}$ Pirmuoju infrastruktūros bumu pripažistama britų ,, manija geležinkeliams“, kilusi apie 1840 m., tačiau ir tuomet infrastruktūros projektai sudarè tik 5 proc. D. Britanijos BVP (žr.: Ten pat).

${ }^{24}$ Ekonomikos teorijoje tai koeficientas, parodantis, kaip pajamų kitimas priklauso nuo investicijų; uždarose ekonomikose be aktyvaus ekonomikos politikos formavimo k=1/MPS, kai angl. MPS - Marginal propensity to save arba $\Delta \mathrm{S} / \Delta \mathrm{Y}$ - polinkio taupyti ir pajamų pokyčių santykis (žr.: Blanchard, Oliver, Macroeconomics, New Jersey, Pearson Education, Inc., 2006, p. 445).
} 
Verslo sluoksniuose tikima, kad investicijos Kinijoje duoda gerą finansinę grąžą. Tą patvirtino JAV - Kinijos verslo tarybos (ang. US-China Business Council) bei ES Prekybos rūmų (ang. EU Chamber of Commerce) atliktos investuotojų apklausos. Jų duomenimis, 83 proc. investuotojų i Kinijos ūki 2007 m. gavo jų lūkesčius pateisinusi pelno dydi, o 2/3 respondentų nurodè, kad jis prilygo vidutiniškam ju kompanijos rodikliui - pelno norma buvo tokia pat, kaip ir kompanijos padaliniuose kitose valstybėse. 84 proc. apklaustuju nurodè, kad Kinijoje buvo investuojama siekiant prioritetiniu strateginiu kompanijos tikslų: 46 proc. taip kūrèsi platformą eksportui į kitas Azijos rinkas, o 28 proc. - gaminiams eksporto forma sugrąžinti i JAV. 85 proc. apklaustų verslininkų nurodè, kad Kinijos padalinių pajamos 2007 m., lyginant su ankstesniais metais, smarkiai išaugo, o 61 proc. respondentų neabejoja, kad analogiško dydžio pajamas ju padaliniai Kinijoje generuos ir 2008-2010 metais $^{25}$. Belieka prisiminti fundamentalų racionaliujų lūkesčių teorijos teigini - būtent lūkesčiai per ilgesnị laikotarpi veikia paklausą, lemiančią gamybą. Pasikliaudami prielaida, kad rinkos dalyviai savo ateities lūkesčius formuoja, geriausiu būdu pasinaudoję visa turima informacija, kartais netiesiogiai, tik vadovaudamiesi viešais ar privačiais ekspertų vertinimais, galime suprasti pasaulio ekonomikos raidos tyrinėtojų nuogąstavimus, jog Kinija iš regioninio konkurento virsta globaliu konkurentu.Didžiulè investavimo programa, kuriai yra subrendusi Kinijos ekonomika, gali įtraukti lig šiol laikytas fantastiškomis privataus kapitalo apimtis. O tai, prognozuotina, išjudins šalies vertybinių popierių rinką, ypač paklausą ilgos trukmės VVP, bei įteisins naujus investicijų reguliavimo pakeitimus.

\subsection{Naujasis pasaulio finansų vadybininkas}

Pasaulio finansininke Kinija pradèta vadinti 2008 m., kad buvo susivokta, kad jos einamosios sąskaitos perviršis nuo 1-3 proc. šio dešimtmečio pradžioje padidëjo iki 9,5 proc. ir auga toliau, o kapitalo sąskaitos balansas daugybę metu yra teigiamas ir vis dideja.

Nors oficialiose tarptautinių institucijų ataskaitose teigiama, kad verslo sąlygos Kinijoje tebėra gana sudètingos, o kai kuriuose sektoriuose vykdoma protekcionistine politika $^{26}$, šalies ūkis pritraukia vis daugiau tiesioginiu užsienio investicijų (TUI). Užsienio kapitalo įmonès, manoma, yra pagrindinis TUI Kinijoje tikslas. Tokio tipo įmonės $2007 \mathrm{~m}$. sudarè apie 78 proc. visų naujai įteisintų investicinių struktūrų. Nors bendras skaičius investicinių projektu, kuriuos buvo leista Kinijoje vykdyti 2007 m., lyginant su ankstesniais metais, nuo 41485 sumažejo iki 37888, tačiau finansinio kapitalo jie pritraukè 13,8

\footnotetext{
${ }^{25}$ „Special Report: Strategic Economic Dialogue Aftermath“, http://www.uschina.org, 20080704.

${ }^{26}$ Ribojamos tiesioginès investicijos, susijungimai bei įsigijimai - taikomi ịvairiausi barjerai, neaptarti Kinijos narystès Pasaulio prekybos organizacijoje (nuo $2001 \mathrm{~m}$.) sutartyse.
} 
proc. daugiau - absoliuti suma sudarè $82,66 \mathrm{mlrd}$. JAV dol. ${ }^{27}$ Todèl investicinès aplinkos apžvalgose teigiama, kad, kaip ir ankstesniais metais, taip ir 2008-2010 m. Kinija turètų išlikti viena iš 5 populiariausių pasaulio finansinio kapitalo judejjimo krypčių ${ }^{28}$. Nors didžiausia užsienio kapitalo dalis 2007 m. teko Kinijos apdirbamajai pramonei - per 40 mlrd. JAV dol., o transportui, sandèliams, paštui, telekomunikacijoms ir kitoms infrastruktūru projektams vystyti teko tik apie 2 mlrd. JAV dol., tikètina, kad 2008 m. statistikos rodikliai parodys ryšku pokyti pastarosios investavimo krypties naudai.

Tačiau vis ryškesni tampa požymiai, kad spekuliatyvaus kapitalo banga, Kinijoje susiformavusi 2008 m., bus žymiai didesnè nei kada pasaulio ekonomikoje yra buvusi. Iki šiol buvusi rinkų pažinimo patirtis jau tampa per menka, bandant suvokti šio reiškinio priežastis ir galimas pasekmes. Kaip bedèliotu sumas iškiliausi pasaulio analitikai, jie negali paaiškinti, iš kur Kinijos vidaus rinkoje per penkis 2008 m. mèn. atsirado apie 214 mlrd. JAV dol. Didejjančiu šalies prekybos sąskaitos pertekliumi ir TUI paaiškinama tik apie 30 proc. susidariusio oficialaus užsienio valiutos prieaugio ${ }^{29}$. Todèl vis populiaresnè tampa mintis, kad Kinijos finansų rinka niekuo nesiskiria nuo kitų besivystančių rinkų su prigimtiniu reiškiniu - „karštaisiais pinigais“. Pavyzdžiui, Michael Pettis iš Pekino universiteto Guanghua verslo mokyklos teigia, kad tokiu pinigu kiekis Kinijos ekonomikoje siekia apie 200 mlrd. JAV dol. Skaičių mokslininkas grindžia prielaida, kad daug užsienio kompanijų deklaruojamus TUI ir eksporto rodiklius perdeda, o ị Kiniją patenkantys finansinio kapitalo srautai viršija investiciju poreiki, todèl „ir dirba kur nors kitur“30.

Statistikos žinynuose skelbiama, jog pagrindiniai investicijų i Kinijos ūki šaltiniai jau kelerius metus išlieka tie patys - pagal apimčių dydį iš eilès rikiuojasi Hong Kongas, Didžiosios Britanijos Mergelių salos, Pietų Korėja, Japonija ir Singapūras. 2007 m. duomenimis, iš "stipriausio“ investuotojų dešimtuko, kuriam priklauso apie 87 proc. visų investicijų i Kinijos ūki, iškrito vienintelè jame buvusi ES valstybè - Vokietija. Jos portfelio dydis sumažèjo 63,4 proc. investicijas perėmė savininkai iš Mauricijaus, Vakarų Samoa, Kaimanų salų ir JAV. Situacija Kinijos rinkoje buvo pavadinta fenomenu, sukẻlè susirūpinimą Kinijos valstybinèms valiutų priežiūros administravimo bei mokesčių administravimo institucijoms. Ju duomenimis, bent 2/3 TUI tampa pirmyn ir atgal keliaujančiais pinigais, kai įmonès ir atskiri asmenys dideles sumas perveda i „,mokesčių roju“ ir TUI pavidalu susigrąžina atgal į Kiniją ${ }^{31}$. Ir, be abejonės, pasinaudoja verslo lengvatomis, kurių vis daugiau siūlo Kinijos vyriausybè.

2007 m. pasaulio finansų rinkos tyrinėtojų dėmesį atkreipè nauji „žaidèjai“ - KLR nepriklausomas turto fondas (angl. PRC's sovereign wealth fund) ir Kinijos investuotoju korporacija (angl. CIC). Pastaroji įsigijo 3 mlrd. JAV dol.

\footnotetext{
${ }^{27}$ Report (note 25$)$.

${ }^{28}$ Ten pat.

${ }^{29}$ „Hot and bothered“, The Economist, 28 June 28 2008, p. 81.

${ }^{30}$ Ten pat.

${ }^{31}$ Report (note 25$)$.
} 
vertès Blackstone akcijų paketa, 9,9 proc. Morgan Stanley akciju, už jas sumokèdama 5 mlrd. JAV dol. Skelbiama, kad per 2008 m. Kinijos investuotojai įsigis turto užsienyje už 37 mlrd. JAV dol., kai 2007 m. ši suma sudare 26 mlrd., 2006 m. - 21,2 mlrd. Nors Kinijos vyriausybès dalis sandoriuose nèra viešinama, manoma, kad ji sudaro apie 86 proc. $^{32}$

Tuo metu, kai galinga rinkos jẻga prekyboje, pinigais ar užsienio investicijomis siekia peržengti tiek Kinijos, tiek kitų valstybių sienas, išvengti politinès ar ekonominès kontrolès ir integruoti įvairių valstybių visuomenes, valstybės biurokratijos interesai ir valstybės logika Kinijos ekonominių kovu arenoje išlaiko ypatingą statusą. Kaip prieš du dešimtmečius prognozavo Robertas Heilbroneris ${ }^{33}$, kad konkuruojančiose valstybėse kapitalo kaupimą per vyriausybes visada bus stengiamasi paimti į savo rankas ir kontroliuoti, priversti tarnauti valstybëje numatytiems tikslams bei galingoms įtakos grupems valstybės viduje, taip ir vyksta šiandieninejje Kinijos Liaudies Respublikoje.

\subsection{Ekonominis nacionalizmas - kova už didybę}

Prieš ketvirtį amžiaus buvo prognozuojama, kad Azijos valstybių ekonominio šuolio galima tikètis, kai jose bus patenkintos trys pagrindinès sąlygos. Pirma, turètų susiformuoti stipri nacionalinė biurokratija, kuri nustatytu, kuo reikia užsiimti pirmiausia, kokie prekybiniai, investiciniai ir kitokie komerciniai susitarimai gali pasitarnauti nacionaliniams interesams ir tenkinti sąlygas, kuriomis šalies ekonomika sąveikautų su didesne pasauline ekonomika. Antra, turètų būti daromos didžiulès investicijos į mokslą ir žmogiškajį kapitalą. Trečia, šalyje turètų būti leidžiama veikti rinkos dėsniams, o skirstant išteklius turi būti vadovaujamasi kainų faktoriumi ${ }^{34}$. Pramonės vystymuisi palanki politika - tai bet kurios augančios valstybès karinès galios ir nacionalinio saugumo garantas, bet turto kaupimas ir jėgos santykiai tarp nevienodos galios rinkos dalyvių dažnai išprovokuoja ekonominio nacionalizmo atsiradimą.

Kinijos ekonomikoje jau daugybę metų nėra nuoseklaus požiūrio į užsienio kapitalo reikšmę valstybès ūkiui - palankumo ir priešiškumo nuostatos keičia viena kitą. Todèl pasaulio versle sudaromo problemų ir rūpesčių dešimtuko sąraše pastarasis Kinijos aspektas vertinamas kaip vienas svarbiausių ${ }^{35}$. Kinijos ekonominės politikos formuotojai atvirai skelbia, kad užsienio kapitalą reikia priversti dirbti taip, kad jis skatintų vietines inovacijas. Investiciju „,kokybės" parametrai aptariami pagrindiniuose politiniuose šalies dokumentuose, pavyzdžiui, 11-ajame pažangių technologinių šakų vystymo penkmečio plane ir 2007 m. gairèse užsienio investicijoms pritraukti. Kinijos vyriausybė bando užtikrinti, kad kuo didesni finansiniai ištekliai būtų nukreipti į naujų ir mo-

\footnotetext{
${ }^{32}$ Ten pat.

${ }^{33}$ Heilbroner, Robert L. The Nature and Logic of Capitalism, New York: W. W. Norton, 1985, p. 94-95.

${ }^{34}$ Hofheinz, Roy Jr., and Calder Kent E., The Eastasia Edge, New York: Basic Books, 1982, p. $24-28$.

${ }^{35}$ Report (note 25).
} 
dernių technologijų vystymą, todèl 2007 m. buvo paruošta ir įteisinta ypatingo politinio dokumento - Investavimo žinyno (ang. Catalogue Guiding Foreign Investment in Industry) - nauja redakcija. Dokumente aiškiai atskleidžiamos visos Kinijos vyriausybei priimtinos investavimo „vietos" ir aprašomos paskatos, kurių galima tikètis iš šalies vyriausybès, pasirinkus jos siūlomą veiklos sritį. Tačiau, kaip ir ankstesnėse analogiško dokumento redakcijose, šalies pramonès šakos tebėra skirstomos i 3 kategorijas - kur investicijos yra skatinamos, kur - ribojamos ir kur - draudžiamos. I ",varžomu“ kategoriją naujoje Žinyno redakcijoje pateko ir kelios papildomos veiklos rūšys - tai eksporto organizavimo veikla ir daug energijos išteklių reikalaujančios chemijos pramonès, mašinų ir ǐrengimu gamybos bei žemès ūkio sritys.

Tačiau didžiausią nerimą užsienio kapitalo valdytojams Kinijoje bei potencialiems investuotojams kelia naujasis Antimonopolizmo ir konkurencijos įstatymas, kuriuo nuo 2008 m. rugpjūčio 1 d. po 14 metų santykinio centralizmo ketinama reguliuoti ekonomiką. Kinijos teisès ekspertai, pristatydami ir komentuodami naujaji cokumentą, vadina ji „ekonomikos konstitucija“ ir teigia, kad pagaliau valstybeje centralizuotą planavimą ir valstybinę nuosavybę ims keisti rinkos santykiai ${ }^{36}$. Pasak rengëju, naujasis įstatymas atspindi dabartinès Kinijos vyriausybès tikējimą, kad ekonomikos restruktūrizacija, prasidèjusi po Mao mirties, toliau gali būti tęsiama tik tuomet, kai šalies vidaus vartotojai turès galimybę naudotis konkurencijos teikiama nauda - žemomis produkcijos kainomis ir aukštesne kokybe. Nuo 2006 m. konkurenciją reguliuojantys ir vartotojus ginantys įstatymai, pasak valdžios atstovu, tapo panašūs ị daugelyje valstybiu egzistuojančius ",bedančius“, skaidrumo stokojančius biurokratijos „žaislus“. Dominuojančios šalies kompanijos esą jau kurį laiką primeta valstybei savo kainu politiką ne tik strateginèse pramonès srityse - energetikoje, transporte, metalurgijoje - bet ir šali aprūpindamos maisto produktais, pavyzdžiui, nustato ryžių grūdų ar makaronų kainas tiek vartotojams, tiek perdirbejams.

Šie ir panašūs vertinimai su naujaisiais Antimonopolizmo ir konkurencijos įstatymo punktais skamba gana ciniškai. Pirma, nors įstatymo įsigaliojimo terminas buvo kelis kartus atidètas, poįstatyminių aktų, aiškinančių atskiru nuostatų taikymo aplinkybes, įstatymo įsigaliojimo dieną nebuvo. Stebėtojai juokauja, kad naujojo įstatymo „skylès" tiek didelès, kiek didelè yra pati Kinija ${ }^{37}$. Pavyzdžiui, įstatymas numato sankcijas valstybės valdomoms monopolijoms tik tuo atveju, kai ju veikla kelia grèsmę ekonominiam ar nacionaliniam šalies saugumui, bet dauguma stambiujų Kinijos kompanijų visada buvo ir išliks valstybinès. Antra, pasiremdama ES praktika, Kinijos vyriausybė naujuoju įstatymu suteikè teisę specialioms kontroliuojančioms institucijoms vertinti ir "laiminti“ kompaniju paraiškas susijungti ar susilieti, jei tai vyksta Kinijos teritorijoje arba turi įtakos kitoms vietos įmonėms. „Palaiminimo“ verslininkai privalès laukti nuo 30 iki 180 dienu, pagrindiniai kriterijai palankiai išvadai - „technologinè pažanga“ arba "nacionalinės ekonomikos vystymas".

\footnotetext{
${ }^{36}$ „Busting trust“, The Economist, 19 July 2008, p. 67.

${ }^{37}$ Ten pat.
} 
Akivaizdu, kad naujasis įstatymas yra orientuotas tik į užsienio kompanijas, kurios patirs daug papildomų kaštu, jei sutarusios su verslo savininkais kinais, bandys plèsti savo įtaką. Trečia, naujajame įstatyme nèra aptarta, kokiais kriterijais nustatoma, kad kompanija yra "dominuojanti“, todèl atskirais atvejais, neabejotina, kils neišvengiami konfliktai dèl intelektualinės nuosavybès teisių. Pavyzdžiui, Kinijos programinès įrangos ir farmacijos sektoriuose, kaip buvo teigiama lig šiol, dominuoja kelios užsienio kompanijos. Tiesioginis naujojo įstatymo taikymas leidžia jų veiklą apriboti, pavyzdžiui, atšaukiant ar suvaržant licenzijas konkrečios produkcijos gamybai, kuri paprastai būna susijusi su dideliais išankstiniais mokslinio ir tiriamojo darbo kaštais, perkeliamais i produkcijos kainą per ilgaji veiklos laikotarpį. Ketvirta, kova dèl instituciniu galių kontroliuoti naujojo įstatymo vykdymą jau spejjo išryškinti svarbią Kinijos ekonomikos problemą - nacionalinio lygio biurokratijos inerciją ir sieki turèti viršenybę prieš regionų biurokratus, kurie iki šiol buvo igalioti reguliuoti vietos kompaniju, tarp jų ir užsienio kapitalo, veiklą. İstatymo įsigaliojimo dieną dar nebuvo paskelbta, kokia institucija kontroliuos jo vykdymą šalyje. Pasaulio spaudoje prognozuojama, kad „didysis prizas“ bus padalintas trims institucijoms, kurios atstovauja tam tikras prekybos interesu grupes, visokeriopai remiamas valstybès kontroliuojamoje ekonomikoje.

Šie faktai provokuoja prielaidą, kad Kinijos nacionalinè biurokratija, pernelyg pasiduodama gynybinio ekonominio nacionalizmo diktatui ir siekdama neproporcingai didelès ekonominès naudos sau, gali prarasti pagrindini ekonominio augimo protrūkio stimuliatorių - užsienio investicijas. Juolab, kad vis dažniau paskelbiama faktų, iૃrodančių, jog Kinijos ekonomika yra pernelyg sofistikuota, kad šalis stokoja savų idejju, inovacijų ir technologiju - skolinasi viską nuo "galvos iki koju“", nesukuria pridedamosios vertès. Iki šiol ji konkuravo ne inovacijomis ir kokybe, o tik pigia darbo jèga: pavyzdžiui, jei 2003 m. Kinijoje surinkto televizoriaus kaštai sudarè vidutiniškai 73 JAV dol., tai Malaizijoje buvo dvigubai, o JAV - keturis kartus didesni. Pasak Nicholas Lardy iš Petersono Tarptautinés ekonomikos instituto ${ }^{38}$, laikotarpis, kurio Kinijai reikia, kad iš didelès pridedamosios vertės importuotojos taptų šalimi eksportuotoja, truks dar kelis dešimtmečius.

\footnotetext{
${ }^{38}$ Jo skaičiavimu, IT gaminiai, kurių iš Kinijos 2006 m. buvo eksportuota už 300 mlrd. JAV dol. (daugiausia pasaulyje), pareikalavo importuotų komponentų už $226 \mathrm{mlrd}$. JAV dol., tai reiškia tik 15 proc. pridètinę vertę; visos Kinijos modernių technologiju imonès yra pigios ir menkai kiniškos - pagal pajamas stambiausių kompanijų dešimtuke nėra nei vienos kinų kapitalo įmonės; užsienio investuotojams priklauso penktadalis visų Kinijos IT įmonių aktyvų ir apie 20 proc. sektoriuje sukuriamų pajamų, jiems dirba apie 16 proc. Kinijos gyventojų; nors darbo užmokestis lieka šalyje, savininkų-užsieniečių pelnas kaip TUI reinvestuojamas ị kitas veiklos sritis, o technologijos priklauso industrinėms valstybėms (žr.: „A special report on technology in India and China“, The Economist, 10 November 2007, p. 7).
} 


\section{Visuomenè, kur milijonas nèra reikšminis skaičius}

Kinijoje ryškëja du požiūriai į valstybės galios, kartu ir ekonomikos augimo perspektyvą. Pirmasis vadovaujasi tradicinių rodikliu - BVP ir užsienio investiciju - pokyčio analize. Nuomonių ir prognozių laviną formuoja tarptautinès agentūros, akademinès institucijos, „,protingos galvos“, įvairiu pakraipu leidiniai ir interneto svetainès. Nors visada primenama, kad Kinijos spauda ir informacija yra valstybės varžoma sritis, skelbiant faktus nurodoma į šalies vidaus, Honkongo ir Taivano ekspertu publikacijas kinų kalba. Kitas požiūris remiasi retai viešinamų Kinijos memorandumų ir vidaus politikos dokumentų analize. Taip kyla nauja vertinimų ir debatų banga - dėmesys yra nukreiptas į Kinijos užsienio politiką ir socialinès atskirties problemas valstybëje. Vis dažniau yra kartojama mintis apie „dūstančią“ ir „kurstančią“ Kinijos valdžią bei jos užsienio politiką, kylantį marksizmo ir Mao ideologinį paveldą joje $\mathrm{e}^{39}$. Masačusetso technologijos instituto profesorius Yasheng Huang savo studijoje ${ }^{40}$ atkreipia dèmesį į kainą, kurią moka kinų tauta už galimybę vadintis fenomenu, ir teigia, kad Kinija yra dvilypè valstybè. Viena pusė - tai urbanizuotą ir valstybės kontroliuojamą gyvenimą turinti tautos dalis, kita - rezonuojanti, nuo smulkaus verslo priklausanti kaimiška tautos dalis, kuri prasta gyvenimo kokybe, augančiais mokesčiais "finansuoja“ urbanizacijos augimą. Pasak Yasheng Huang, socialinė atskirtis ir skurdas Kinijos provincijoje nerodo tendencijų nykti. Tai patvirtina, pavyzdžiui, faktas, kad 2000-2005 metais, kai buvo masiškai uždaromos mokyklos ir ligoninès kaimo vietovėse, neraštingu suaugusių kinų skaičius padidèjo 30 milijonų.

Iki šiol akademikai nesutaria, kur glūdi atskiru valstybių ar visuomenės grupių skurdo priežastis. Visas žinomas teorijas bandoma skirstyti į tris grupes: pirmoji apima teiginius, kad vargstantieji tiesiog blogai dirba, ir tik efektyvi ekonomika gali juos išlaisvinti iš skurdo, antroji - kad vargšai neturi galios ir todèl yra išnaudojami, tad turi igyti valstybinę valdžią, trečioji - kad jie yra patekę i ydingą skurdo ratą, kurị tik kažkas iš išorès gali nutraukti ${ }^{41}$. Tačiau moderniu tiesioginių komunikacijų laikais atokiausiose vietovėse gyvenantiems žmonėms nesunku sužinoti apie kitų turtus ir privalumus, kuriuos teikia materialinė pažanga, ir skurdas nebėra priimamas kaip natūrali būsena. Kinijos situacija rodo, kad milijonų skurstančių žmonių viltys gyventi geriau, kitaip lūkesčiai, negali būti vadinami racionaliais - jie pralenkia visuomenès galimybes paversti viltis

\footnotetext{
${ }^{39}$ „China Analysis: 19“, European Council on Foreign Relations, Asia Centre, Sciences Po, http://www. centreasia.org., 20080814.

${ }^{40}$ Huang, Yasheng, Capitalism with Chinese Characteristics: Entrepreneurship and the State, Cambridge University Press, 2008, p. 368.

${ }^{41}$ Manoma, kad pirmasis tokią skurdo priežasčių klasifikaciją pasiūlè Ragnar Nurkse (žr.: R.Gilpin, Tarptautiniu santykiu politinè ekonomija, „Algarvė“, 1998, p. 487).
} 
tikrove, galima sakyti, tėra žmonių elgsenos dėsningumas ${ }^{42}$. Tačiau didžiuju skaičių dèsnis, kai kalbame apie socialinès atskirties problemas ir galimą nepasitenkinimo bangos jẻgą, tampa labai aktualus. Kita vertus, Kinijos politinio elito ideologijos dalimi yra manipuliavimas materialinės gerovès vizija, kaip ir siekis demonstruoti pasauliui visuomenès modernumą ir finansinį klestẹjimą, socialinès atskirties problemas netiesiogiai ignoruojant. $2008 \mathrm{~m}$. pirmoje pusëje Pekino olimpinių žaidynių faktas buvo minimas prilyginant jị $1936 \mathrm{~m}$. atvejui, kai olimpinės žaidynès įvyko nacistų valdytame Berlyne. Tačiau publikacijose, viešinančiose Kinijos valdžios atstovų ir atskirų gyventojų nuomones, buvo skelbiama, kad tokia analogija tèra dar vienas suirzusių vakarų priešų bandymas sumenkinti nenumaldomą Kinijos galios augimą ${ }^{43}$.

Paprasti keliautojai, kuriuos tiesiog žavi šimtametės Kinijos religijos, kultūros bei medicinos tradicijos, pastebi paprastesnes, glaudžiau su tikrove susijusias „olimpines“ permainas ${ }^{44}$. „Kažkur anapus“ atsidūrè milijonai žmonių, neturinčių tapatybès dokumentų, be išsilavinimo ir socialinių garantijų, kilusių iš skurdžių provincijų, darbo jègos perpildytų kaimų nederlinguose kraštuose. Visi jie - 1949 m. pradètos marazmatinès šeimos planavimo politikos rezultatas ${ }^{45}$. Juos pakeitẻ 500 tūkst. besišypsančiu paslaugių „,savanorių", valstybės mobilizuotų talkinti svečiams žaidynių metu.

Panašu, kad išsklaidytoji žmonių masè, kuri neoficialiais skaičiavimais siekia 200 mln., nepatenka į Kinijos vyriausybės skelbiamą „,harmoningos visuomenės" sukūrimo planą, kuris, žadama, bus įgyvendintas iki 2020 m. Pastarasis planas skirtas kitiems milijonams kinu - tiems, kurie vadovaudamiesi dvigubais standartais, liberaliosios vakarų demokratijos pasiekimus skelbia suklastotais, kaltina industrinių šalių verslininkus perkẻlus į šalį taršius gamybos procesus, o dabar kėsinantis iz „naujujų" kinų teisę mėgautis nuosavais automobiliais ir judejjimo laisve. İ harmoningos visuomenès kūrimo planus, be abejo, nepatenka tiek nacionalistinio pobūdžio, tiek ekonominių priežasčių išprovokuoti incidentai. Paskutiniai paskelbti duomenys apima tik devynis 2006 m. ménesius ir teigia protesto akcijų ir incidentų skaičių sumažẻjus 22 proc., jei lygintume su ankstesniais metais. 2004 m. Kinijoje įvairių protesto akcijų ir incidentų buvo priskaičiuota per 74 tūkst., kai 1994 m. jų buvo tik 10 tūkst. ${ }^{46}$ Antivakarietiški nacionalizmo protrūkiai, i̇ protestų akcijas įtraukiantys milijonus kinų šalyje ir už jos, tampa savotiškai naudingi vyriausybei, kuri gali demonstruoti pasauliui, jog moka ir gali suvaldyti mases, ir nacionalinei biurokratijai, garsėjančiai korupcija ir ypatinga leidimų-draudimų sistema.

Tris dešimtmečius Kinijos vyriausybei pavyko išlaikyti savo galias, kai piešdavo tautai ekonominės gerovės viziją. Milijonai kinų jau dabar mėgaujasi

\footnotetext{
${ }^{42}$ Hirschman, Albert, Essays in Trespassing: Economics to Politics and Beyond, New York: Cambridge University Press, 1981, p. 62.

${ }^{43}$ „China's dash for freedom“, The Economist, 2 August, 2008, p. 11.

${ }^{44}$ Dikčius R., „Geltoni raguočiai“, Istorijos, 2008 m. rugpjūtis, Nr. 8, p. 80.

${ }^{45}$ Pavyzdžiui, Mao Zedong skelbẻ šūkị „Kuo mūsų daugiau, tuo mes stipresni“, vẻliau buvo nustatyta ,vieno vaiko politika“, privertusi valstietes gimdyti ir auginti vaikus nelegaliai.

${ }^{46}$ „A lot to be angry about“, The Economist, 3 May, 2008, p. 61.
} 
susikurtu gyvenimo būdu, apie kokị jų tẻvai net nesvajojo. Tačiau „naujujų kinų protams reikia naujų inspiraciju, ir vyriausybė sukūrẻ naują strategiją pažadejjo, kad jų šalis atgaus „,teisingą" vietą pasaulio ūkio centre. Deja, kaip rodo istorija, bet koks nacionalizmo didinimas dažniausiai atsigręžia priešu ir į šalių vyriausybes.

\section{Vietoj apibendrinimo}

Dabartinė KLR ekonominès, politinès ir kultūrinès-civilizacinės įtakos zona paneigia svarbiausią politinès ekonomijos teigini, kad nacionalinių valstybių ir politiniu sienu pasaulyje yra neišvengiami konfliktai, kai kylančios valstybès bando įveikti egzistuojančius barjerus. Kinų tauta, aktyviai rodydama pasauliui, jog siekia atkurti teisingumo principą hierarchinėje visuomenèje ir susigrąžinti anksčiau turètą galią regione bei pasaulyje, per savo nacionalinę ir regioninę biurokratiją nuosekliai realizuoja toli siekiančią viziją. Didžiulè investavimo programa, kuriai yra subrendusi Kinijos ekonomika, ir pasaulyje susidaręs finansinio kapitalo perteklius, kuris paprastai ieško vietų, kur gali pasiekti didžiausią ribinį pelningumą, atitinka kinų racionaliuosius lūkesčius. Suvokusi moderniausio ekonomikos multiplikatoriaus - infrastruktūros plètros - galimybes, Kinijos nacionalinẻ biurokratija ir toliau galès naudotis užsienio investicijų privalumais, administraciniais ir politiniais sprendimais nukreipdama jas ị sritis, kurios geriausiai tenkina jos pačios interesus. Kinijos vyriausybė galès sẻkmingai valdyti milijardą viršijančios tautos protus ir darbo vaisius, efektyviai manipuliuodama kognityviniu disonansu aiškinama įvaizdžio instrumentų galia. Todèl visai tikètina, kad Kinijai pavyks pasinaudoti didžiuliu ,atsilikusios šalies" pranašumu - galimybe peršokti atskiras ekonominio vystymosi stadijas ir taip pralenkti bet kuri pramoninį lyderị.

Tokią prielaidą provokuoja $2008 \mathrm{~m}$. pasaulio finansinės krizės ištakų ir galimų pasekmių analizė: tampa aišku, kad reikia tikėtis milžiniškų skolų ir bankų nacionalizavimo, ilgalaikès recesijos tiek JAV, tiek Europos valstybėse, nes ketvirti amžiaus šios valstybès suvartodavo žymiai daugiau nei gamino ir nesuvaldè deficito problemų. Komunistinè Kinija „dirbo“ pelningai, taupè ir kaupe turtą. Dabartinè finansinė sumaištis atveria jai galimybę sukauptus pinigus sẻkmingai investuoti Vakarų rinkose - pervesti savo dolerinius rezervus, pavyzdžiui, i̇ JAV aktyvus, taip mažiausiai nekenčiant nuo pasaulinès gamybos mažejimo, palaipsniui pakeisti pasaulio jẻgų santykị ir taip perimti pasaulio galios estafetę. Tačiau prognozuojant nevalia ignoruoti ekonomikoje svarbaus žodžio ,jeigu“... Pavyzdžiui, eksportuojamos prekès darys poveiki infliacijos pokyčiams visame pasaulyje, jeigu dèl įvairių administracinès kontrolès priemonių vidaus kainos ir darbo užmokestis Kinijoje augs žymiai lèčiau nei visame pasaulyje. $2008 \mathrm{~m}$. suaktyvëjęs vidaus paklausos augimas ir toliau veiks Kinijos BVP augimą, jeigu iki šiol vis dar neaiškus pajamų pasiskirstymas 
nesustiprins ir taip ryškios socialinės įtampos šalyje. Pagrindinį ekonomikos augimo stimuliatorių - užsienio investicijas - Kinija išlaikys tik tuo atveju, jei ryškëjančio ekonominio nacionalizmo priemonėmis demonstruojamas nacionalinès biurokratijos siekis turèti viršenybę prieš regionų biurokratus ir tarnauti galingoms įtakos grupėms ims akivaizdžiai nykti.

Išsamesnè skaičių ir faktų analizè, neabejotina, padètų suformuluoti ir daugiau prielaidų bei hipotezių, leidžiančių suabejoti kylančia Kinijos ekonomikos galia. Pavyzdžiui, tai augantis gyventojų skaičius: jei 2040 m. Kinijos ekonomika pagal kai kuriuos rodiklius ir susilygins su JAV ekonomika, tai sukuriamos pajamos vienam gyventojui tesieks 1/4-1/3 amerikiečių lygio. Antra, tiek Vakaru Europos, tiek JAV ekonomikos jau yra "ligotos“, o plintantis užkratas neišvengiamai turètų sumenkinti ir Kinijos ekonomikos rodiklius. Trečia, rimta ir aštrejjančia problema yra Kinijos visuomenės, deklaruojamo socializmo ir rinkos santykių nesuderinamumas, apie kurį kalba net šalies lyderiai ${ }^{47}$. O dèl senkančių naftos išteklių pačioje Kinijos teritorijoje, spartaus industrializacijos, urbanizacijos, žmoniu populiacijos augimo ir ekonominio vystymosi tempu, Kinijoje ir toliau aštrès energetinio saugumo problema. Juk gresiantys žaliavų tiekimo sutrikimai, staigus išteklių kainų pakilimas ne tik rimtai pažeistų Kinijos ekonomiką, bet dar paaštrintų socialines problemas ir išprovokuotų neramumus, galinčius susilpninti valdančiosios komunistu partijos įtaką.

2008 m. rugseijis

\footnotetext{
${ }^{47} \mathrm{Hu}$ Jintao, „Building harmonious socialist society“, Speech at the Special Discussion Class for Principal Leading Cadres, Xinhua, 20050630.
} 